\title{
THE IMPORTANCE OF LOCAL DOCUMENTS IN ENSURING LABOR DISCIPLINE
}

\author{
Bobomurod Chalgashevich Yarashev \\ Independent researcher of the Military-Technical Institute of \\ The National Guard of The Republic of Uzbekistan, \\ Tashkent, \\ Republic of Uzbekistan
}

Article DOI: https://doi.org/10.36713/epra3903

\begin{abstract}
The article analyzes the importance of local documents in ensuring labor discipline, the specifics of labor relations with the help of scientific literature and legal sources as well.

KEY WORDS: labor discipline, local document, labor relations, modernization, civil, internal labor order.
\end{abstract}

\section{INTRODUCTION}

As we carry out comprehensive work on social, economic, political, spiritual and educational reforms aimed at building a new society in our country, modernization and renewal of all spheres of life in line with modern requirements, on the basis of all this the interests of our citizens, their material and cultural life, the goal is to elevate human dignity. One of the peculiarities of labor relations is that, unlike civil law relations, there are internal labor regulations and strict adherence to them by all employees.

\section{METHODS}

Lawyer M.Yu. Gasanov states that one of the main forms of social partnership in the field of labor is the adoption by the employer of local acts in the enterprise in coordination with the employee representative body [1, p.272]. High performance of enterprises and organizations One of the main factors of being is labor discipline. Adherence to labor discipline will also be the basis for the application of incentives to employees.

The content of labor discipline reflects the efforts of employees and employers to perform their mutual obligations conscientiously and clearly. Today, the state has established in laws the minimum level of labor rights and guarantees for employees, ensuring that the interests of the employee, then the employer and the state are protected in labor relations.

\section{RESULTS AND DISCUSSIONS}

The transition to a society based on free enterprise has radically changed the content and purpose of labor discipline. Now the state intervention in the field of labor law and the obligations of citizens have a completely different content.

In the context of market relations, it is important to strengthen labor discipline in today's enterprises, where the well-being of not only the employer but also the employee depends on the results of effective and productive work in the future. Social work requires a strong interaction between its participants, a common goal and task, and a single set of procedures to ensure the achievement of a common goal. In enterprises where tens, even hundreds, and thousands of people work, it is absolutely impossible for everyone to act as they see fit and not obey the general order, because the overall result cannot be achieved unless their goals and aspirations are directed in a single direction. Therefore, in all enterprises and organizations, regardless of the form of ownership, there should be rules of labor discipline, which allow to effectively combine the interests of employees with the interests of the employer, their interests with the interests of the state and society. With the development of state and social relations, which are the subject of labor law, the economic power of the employer, which created the ownership of the hired worker, suppressed the evolution of the relationship between employee and employer to the democratic aspects of 
the employee-employer employment contract passed $[2, \mathrm{p} .122]$.

It is well known that the main reason for the activities of employees and employers is the economic benefit. The income and economic growth of any employer depends on its risk and the correct organization of labor, that is, the systematic establishment of labor discipline for employees in enterprises, in turn, leads to economic development and material interests. Owning a permanent job, that is, the income necessary to live, to feed a family, to enjoy the benefits of life, serves as an economic benefit for employees. Loss of income, the risk of unemployment can be a serious incentive for any employee to follow discipline in today's market economy.

Hence, labor discipline is a means of effectively achieving social, economic, and other goals of production. Ensuring compliance with labor discipline in enterprises leads to an increase in labor productivity, improving the quality of work and, on this basis, an increase in the material and cultural standard of living of all employees. In a free market environment, the importance of discipline is very important, especially in the production process. Because free competition requires every producer, every entrepreneur to achieve more results with less labor and money, to work towards a clear goal. As a result, labor discipline rules constitute the guiding terms of contracts between an employer and an employee.

In this regard, today is characterized by the urgency of issues of labor discipline and legal regulation of relations between employees in the performance of their duties. Each employee enters into a legal relationship with the employer in the course of performing employment duties in accordance with the concluded employment contract. This relationship together creates an internal labor order, which is part of the law and order in society and is limited to the territory of the employer.

Labor discipline and internal labor discipline cannot be seen in isolation. Without proper discipline in production and management, there will be no labor discipline and the social labor process will be disrupted. Therefore, the internal labor regime is mandatory for all persons in the employment relationship, in particular employees and employers. The internal work schedule is equally mandatory for full-time employees, part-time employees, coworkers, part-time employees or part-time employees. The essence of the internal labor order is to ensure its proper organization, regardless of the conditions of use of labor, the subordination of human activity in the labor process, the unconditional adherence to the established labor order.

In practice, the local documents of the enterprise and the employment contract often provide for special features of the termination of the employment relationship at the initiative of the employee, which are not specified in the legislation. The question of how legitimate this is cannot be answered uniformly. It all depends on the local documents and what features are provided in the employment contract. If there are rules that complicate the procedure for voluntary termination of the employment contract, and the employee is assigned any additional duties not provided by law, then it is illegal to include them in the content of local documents or the employment contract. Such conditions worsen the condition of the employee in relation to the legislation and must be declared invalid in accordance with Article 5 of the Labor Code.

In particular, it is illegal to include the following provisions in the local documents of the enterprise and the employment contract with the employee: to extend the period of notification of the employer on termination of the employment contract by more than two weeks (probationary period - three days);

- that the employment contract may be terminated at the initiative of the employee only after he submits a report on the work performed, completes the work started, transfers material assets to his account, signs a statement of indebtedness, fully reimburses the employer and other similar work;

- on termination of the employment contract for an indefinite period at the initiative of the employee, his payment of a penalty;

- on termination of the employment contract at the initiative of the employee only in the presence of valid reasons.

At the same time, the local documents of the enterprise and the employment contract may specify the termination of the employment contract at the initiative of the employee, providing additional guarantees to the employee.

Thus, the rules of the internal labor procedure define the procedure for filing and accepting an application for termination of an employment contract at the initiative of the employee, which is not only acceptable, but also expedient. The inclusion of such clarification may imply certain recommendations to the employee, that employees. Requirements for ensuring the rights of employees should be stated in an imperative form, noting the relevant responsibilities of officials.

For example, as mentioned above, an employee has the right to submit an application for termination of the employment contract directly to the manager, his deputy, personnel department, office, and so on. However, this situation means that an employee who decides to terminate an employment contract sometimes does not know exactly to whom to apply. Therefore, the internal labor regulations provide for the termination of the 
employment contract by the employee to the personnel department, office and similar departments. should be considered. The introduction of such clarification may regulate the filing of an application for termination of an employment contract by employees, which serves the interests of both the employee and the employer.

However, the employee's application bypassing this procedure does not lose its legal force and does not serve as a reason to refuse to satisfy his request to terminate the employment contract. The internal labor regulations may specify the duty of the officials to immediately notify the head of the enterprise, the procedure for registration and registration of such applications, the form of the receipt of the application. Failure of the officials of the enterprise to perform the duties assigned to them in the internal labor regulations may serve as a basis for disciplinary action in the prescribed manner.

\section{CONCLUSION}

The internal labor regulations (other local documents of the enterprise) or the employment contract concluded with the employee may specify the circumstances in which the employment contract must be terminated by the employer at the request of the employee on his own initiative, as the employee may not continue to work. An employment contract, for example, may stipulate the employee's right to terminate the employment relationship at his or her own discretion by giving the employer written notice less than two weeks in advance. Collective agreements of many enterprises provide for additional (not prescribed by law) payments or other benefits in the event of voluntary termination of the employment contract of employees whose employment was terminated on their own initiative due to retirement holds.

\section{REFERENCES}

1. Gasanov. M.Yu. Labor law of the Republic of Uzbekistan. A common part. - T: Publishing house "LESSON PRESS", 2016, -P.272.

2. Kudrin A.S. On the question of the employer's master's power in labor relations // Culture. History. Philosophy. Right. - 2016. - No. 4. - P. 122. 